Cell Research (2000),10, 17-27

\title{
REVIEW
}

\section{Embryonic and genetic manipulation in fish}

\author{
Zhu Zuo Yan*, Yong Hua Sun \\ State Key Laboratory of Freshwater Ecology and Biotechnology, \\ Institute of Hydrobiology, Chinese Academy of Sciences, \\ Luojiashan, Wuhan 430072, China
}

\begin{abstract}
Fishes, the biggest and most diverse community in vertebrates are good experimental models for studies of cell and developmental biology by many favorable characteristics. Nuclear transplantation in fish has been thoroughly studied in China since 1960s. Fish nuclei of embryonic cells from different genera were transplanted into enucleated eggs generating nucleo-cytoplasmic hybrids of adults. Most importantly, nuclei of cultured goldfish kidney cells had been reprogrammed in enucleated eggs to support embryogenesis and ontogenesis of a fertile fish. This was the first case of cloned fish with somatic cells. Based on the technique of microinjection, recombinant MThGH gene has been transferred into fish eggs and the first batch of transgenic fish were produced in 1984. The behavior of foreign gene was characterized and the onset of the foreign gene replication occurred between the blastula to gastrula stages and random integration mainly occurred at later stages of embryogenesis. This eventually led to the transgenic mosaicism. The MThGHtransferred common carp enhanced growth rate by 2-4 times in the founder juveniles and doubled the body weight in the adults. The transgenic common carp were more efficient in utilizing dietary protein than the controls. An "all-fish" gene construct CAgcGH has been made by splicing the common carp $\beta$-actin gene (CA) promoter onto the grass carp growth hormone gene (gcGH) coding sequence. The CAgcGHtransferred Yellow River Carp have also shown significantly
\end{abstract}

* Corresponding author, Fax: 086-27-87876624 E-mail: zyzhu@ihb.ac.cn 
Embryonic and genetic manipulation in fish

fast-growth trait. Combination of techniques of fish cell culture, gene transformation with cultured cells and nuclear transplantation should be able to generate homogeneous strain of valuable transgenic fish to fulfil human requirement in $21^{\text {st }}$ century.

Key words: Fish, nuclear transplantation, transgenic fish,

gene targeting.

\section{INTRODUCTION}

Lives on earth first appeared over 3 billion years ago. As a result of evolution, vertebrates are the utmost advanced life form distributing from seabed to high-mountain. Fishes, at the lower stage of evolution but being the biggest community in vertebrates, include about 21,700 to 28,000 species that take over almost half of the total number of vertebrates[1]. Fishes are also models for experimental study as the eggs are large, fertilization and development are externally and the embryos are transparent. In addition, mono-sexual breeding and crossbreeding between many distantly related species could be done in fishes.

Fish culture is one of the earliest activities of human civilization. Time dating back to 2500 years ago when China was at the Spring and Autumn Period, an ancient Chinese named Fan Li created a great literature "Handbook of Fish Culture" in which domestication and cultivation of common carp in ponds were described in detail. This is the first monograph of fish culture in the world. Since then, Chinese farmers enjoyed a long tradition of selective domestication resulting in very valuable "four farming species" of fish for pond culture. These are black carp (Mylopharyngodon poceus), grass carp (Ctnopharyngodon idellus), silver carp ( Hypophthalmichihys molivrix) and big-head carp ( Aristichthys nobilis). Based on the feeding habits of these fishes, Chinese farmers also invented "multi-culture method" of stocking the four farming species together in the same water body. This is in fact a sustainable ecological system by that farmers are able to gain maximum output with minimum cost. These domesticated species and the multi-culture method have been favorably adopted by other nations abroad.

In addition to the traditional experiences of fish farming, scientists in China initiated some fundamental research in fish cell and developmental biology and molecular genetics leading to a break-through in fish biotechnology. The major achievements are pointed as follows. In 1960' s, Professor Tung T. C. first introduced the art of nuclear transplantation with fish to study the interaction between nucleus and cytoplasm[2]. Tung and his colleagues succeeded in generation of "nuclear-cytoplasmic hybridized fish" between different species (reviewed in [3]). In early 1980's, the first somatic cell 
cloned fish was derived from kidney cells by nuclear transplantation[4]. In 1984, the first batch of transgenic fish was also generated[5]. The development and combination of technologies of nuclear transplantation and gene transfer in fish predicate that a new era in fish breeding is coming; fish directional breeding will revolutionize the traditional fish farming industry.

\section{Nuclear transplantation in fish}

The concept of nuclear transplantation dates back to 1938 when a German biologist, Hans Spermann[6], proposed an experiment that would evaluate the relative importance of the nucleus and cytoplasm in controlling early developmental events. In the early 1950 ' s, the technology of nuclear transplantation was first demonstrated with frogs by Briggs and King[7] and amphibians were becoming most commonly used for studying nuclear transplantation (reviewed in [8]). These studies revealed that the nuclei undergo restriction in developmental capacity as cells became differentiated. Although several experiments suggested that differentiated somatic cells still had developmental totipotency[9-11], the cell differentiation didn't necessitate any irreversible changes in nuclear genetic material. Some subsequent experiments with differentiated somatic cells from Xenopus[12],[13] and Ranna pipens[14-17] could hardly supported the previous cases because that nuclei from these cells only supported the ontogenesis to feeding-stage of tadpole but not to an adulthood. Thus, whether ultimately differentiated cells have the capacity to support the reconstructed embryos to complete their full ontogenesis still remains unanswered. Illmensee and Hoppe in 1981 first succeeded in nuclear transplantation in mammals[18]. They reported that an inner cell mass nucleus could support early development of an enucleated egg in mouse. Three years latter, McGrath and Solter[19] reported nuclear transplantation in mice by using micrioinjection coupled with cell fusion technique. Since then, embryonic nuclear transplantation in sheep, calve, rabbit, porcine and goat were successively done[20-24]. In 1997, the birth of cloned lamb "Dolly" derived from an adult mammary gland cell marked the beginning of a "golden-age" in animal cloning[25]. Recently, success has also been announced in cloning mice, goat, and cattle derived from differentiated cells: fetal fibroblasts[26], muscle cells[27], cumulus cells[28], [29] or oviductal cells[29]. Successes on somatic cloning conclusively revealed that differentiated adult cells still remain totipotent and maintain the whole genome to support normal development to term.

In amphibian and mammals, nuclear transplantation has been successfully done within the same species. In other words, the donor of nucleus and the host of enucleated eggs must come from the same species. On the other hand,“Tung's fish” brought an absolutely new story. Tung' s embryonic nuclear transplantation in fish involves three steps in general[2],[3]. (1) Preparation of donor cells: the blastoderm was separated from the yolk with a fine glass needle, and carefully placed in Holtfreter's dissociation solution for further separating into individual cells. (2) Preparation of unfertil- 
Embryonic and genetic manipulation in fish

ized host eggs: the mature eggs stripped from the female were dichorionized with a pair of forceps, and enucleated by inserting a sharp glass needle into the egg cytoplasm just underneath the site of the second polar body. (3) Nuclear transplantation: after donor cell was sucked into the micropipette by a slight negative pressure and microinjected into the enucleated eggs, the reconstructed embryos were put into Holtfreter's solution for further development. Great successes of fish nuclear transplantation were achieved between different genus (common carp (Cyprinus Carpio Linnaeus) and crucian carp (Carassius aurantus)[30],[31] and different subfamilies (grass carp (Ctenopharyngodon idellus) and blunt-snout bream (Megalobrama amblycephals))[32],[33]. The nuclearcytoplasmic hybrid fish revealed that while most phenotypic characteristics were controlled by the nucleus, a few were controlled by the cytoplasm or by both (reviewed in [3]).

In 1984, the first somatic cell cloned fish derived from short-term cultured kidney cells of triploid crucian carp was produced[4]. In this experiment two rounds of nuclear transfer were carried out. In the first round, the nucleus (3n) was transferred into the enucleated eggs (2n) of crucian carp. There were $41 \%$ of the injected eggs developed into blastulae but no future development occurred. Nuclei from the blastulae were taken for second round of transfer into another batch of enucleated eggs (2n). In the second round, 8 gastrula generated and one of them developed into a fertile female fish (1.2\%) with normal morphological features of crucian carp. The chromosome number was triploid $(3 \mathrm{n}=150)$. This was the first case of cloned animal with somatic cells in fishes. It suggested that some nuclei of somatic cells, following two rounds of nuclear transplantation, could be reprogrammed to totipotent status as zygotic nucleus does.

Nuclear transplantation in fishes, as an approach for studying the relative roles of nucleus and cytoplasm in controlling the characteristics, had also been considered as a helpful method in obtaining new farming strains of fishes. Yan[3] indicated that the nuclear-cytoplasmic hybrid was $22 \%$ higher in growth rate, $3.8 \%$ higher in protein content and $5.58 \%$ lower in lipid content than that of the control, respectively. The art of nuclear transplantation in fish, however, not only requires very skilful manipulators but also bring about very low efficiency in producing the nuclear-cytoplasmic hybrids. The application of nuclear transfer fish in fishery is, thus, under restriction to a certain extent.

\section{Gene transfer in fish}

People never give up their effort on pursuing of breeding new strains of farming species with high quality. Meanwhile, researchers are seeking for some genetic materials other than the whole cell nucleus for transfer. Around the late 1970's, researchers in China introduced the genomic DNA of common carp into the fertilized eggs of Mud carp (Cirrhina molitorella), a tropical species. About 8\% of the "total DNA-transferred" founder Mud carp showed increase of cold-resistance [Zuoyan Zhu, et al. unpublished data]. 
In early 1980 ' s, with the advancement of techniques in molecular cloning and embryonic micro-manipulation, recombinant genes are able to be constructed and transferred into the host animals. The transgenic "super mouse" was the most stimulating report in transgenic studies[34].

The first batch of faster growing transgenic fish was generated by introducing a recombinant human growth hormone (hGH) gene capped with a mouse metallothionein1 (MT) gene promoter into goldfish in 1984[5]. In this study, fertilized eggs of goldfish were obtained by artificial spawning and insemination and the chorion of eggs were removed by digestion in $0.25 \%$ trypsin solution. About 1-2nl of DNA solution containing about $10^{5}-10^{6}$ copies of the MThGH gene was delivered with a micromanipulator into the germinal disc just underneath the second polar body. All the manipulated eggs were carefully put into Holtfreter's solution for further development. By Southern hybridization, more then $50 \%$ of the founders are transgenics. Since then, dozens of laboratories all over the world began to show great zeal for the study of transgenic fish[35], and gene transfer into fish embryos were performed in several species, such as rainbow trout. (Salmo irdeus Gibbonsi), Atlantic salmon (Salmo salar Linnaeus), tilapia (Oreochromis nilotica), medaka (Oryzias latipes), common carp, zebrafish (Danio rerio), loach (Misgurnus anguillicaudatus), catfish (Parasilurus asoltus Linnaeus), etc[36]. Some other techniques, e.g. electroporation[37] and sperm-mediating[38], [39], were also successfully employed in producing of transgenic fish. In addition to gene transfer with GH gene, other types of genes were also employed in gene transfer in fish. For example, GFP (green fluorescent protein) gene was transferred into fertilized eggs of zebrafish as a reporter[40] and AFP (antifreeze proteins) gene was introduced into Atlantic salmon to gain freeze-resistant salmon[41]. However, gh is so far the most commonly used and most thoroughly investigated type of transgenes.

It was in a transgenic fish model that the behavior of a foreign gene, this time the MThGH gene, in embryogenesis was intensively studied by Zhu et al[42]. Southern blotting revealed that the behaviors of MThGH gene in host fish were a dynamic process, including replication, degradation, concatemer formation, and integration during embryogenesis. The replication began at very early stage of cleavage and suddenly took place at late-blastula to early-neurula stages. After neurula stage, most of the foreign gene were migrating with the host chromosomal DNA as revealed on the agarose gel by electrophoresis. It was suggested that foreign gene at these stages was in form of either large concatemers situated outside the chromosomes or integrated into the host genome. If the integration occurred at germ line cells of the host fish, the transgene could be inherited to their offspring. Northern hybridization showed that the transcripts of hGH gene could only be found at post-late-gastrula stage, which was consistent with the timing of the differentiation of fish embryonic cells. As a result of the expression of MThGH gene, transgenic fish showed significantly faster growing trait. On the other hand, a certain proportion of the founders did not show growth enhancement and a few even grew slower than the control. This unexpected observation was reasonable when 
Embryonic and genetic manipulation in fish

the multi-sited integration and transgenic mosaicism were taken into account. In the case of the generation of transgenic mammals, foreign gene had been microinjected into the zygotic pronucleus, which resulted in the integration of foreign gene occurring mostly before the first cleavage[43]. It was believed that the status of transgene in founder mammals was in a homozygous form, which could be transmitted to next generation in a Mendelian manner. However, pronucleus of fish eggs is not visible and the foreign gene could only be microinjected into their cytoplasm. The foreign gene integration in fish was found to be spanned over a long time course from gastrula to late developmental stages resulting in multi-sited integration and consequent transgenic mosaicism. Three categories of transgene integration could be deduced: functional integration, silent integration, and toxic integration. It is only in the functional integration that the transgene was integrated into host genomic sites suitable for expression and therefore showing "fast-growth" trait. Thus, the founder generation $\left(\mathrm{P}_{0}\right)$ of transgenic fish was far from a genetically homogeneous strain.

The specific growth rate (SGR) of $\mathrm{P}_{0}, \mathrm{~F}_{1}$, and $\mathrm{F}_{2} \mathrm{MThGH}$-transgenic fish, as well as of F4 generation was significantly higher than that of the controls[42],[44-47]. Bioenergetic analysis on MThGH-transgenic fish compared with controls was thoroughly worked out. When feeding with fresh tubificid worms, the energy budget of both transgenic and control fishes can be expressed by the following equations[46]:

\section{MThGH-transgenic}

$$
\mathrm{F}_{2} \text { fish } 100 \mathrm{C}=8.9 \mathrm{~F}+0.63 \mathrm{U}+49.03 \mathrm{R}+41.44 \mathrm{G}
$$

\footnotetext{
Control fish $100 \mathrm{C}=7.37 \mathrm{~F}+1.14 \mathrm{U}+53.36 \mathrm{R}+38.13 \mathrm{G}$

In which, $\mathrm{C}$ is the total energy from food, $\mathrm{F}$ is the energy lost in faeces, $\mathrm{U}$ is the energy lost in nitrogenous exaction, $\mathrm{R}$ is the energy channelled to metabolism and $\mathrm{G}$ is the energy channelled to growth.
}

Compared with the controls, transgenic fish had a significantly higher proportion of food energy channelled to $\mathrm{G}$ and a significantly lower proportion of that channelled to $\mathrm{R}$ and $\mathrm{U}$. The transgenic fish saved $6.62 \%$ of the total energy from eaten food for growth improvement. That phenomenon was named as "fast-growing and lesseating" effect. Growth and feed utilization by MThGH-transgenic F4 fish feeding with diets containing different protein levels had also been carried out[47]. Protein and energy intakes were significantly higher in the transgenics than in the controls fed with $20 \%$ protein diet, and recovered energy, as a proportion of protein intake, was also significantly higher in the transgenics than in the controls fed with $40 \%$ protein diet. It was thus concluded that at a lower dietary protein level, transgenics achieved higher growth rates mainly by increasing food intake; but at a higher dietary protein level, transgenics achieved higher growth rates mainly through higher energy conversion efficiency. That is to say, transgenics are more efficient in utilizing dietary protein 
than the controls, which leads to transgenics getting a significantly higher specific growth rate than the controls. For the body composition, it was revealed that the transgenic fish had body contents of dry matter $1.6 \%$, and protein $2.2 \%$ to $4.3 \%$ higher than those of the controls, but contents of lipid 3.9\% to $13.1 \%$ lower than that of the controls[48]. The apparent digestibility of amino acids tends to be higher in the transgenics than in the controls, especially in fish fed diets with lower protein levels. While taking a look at the proportion of amino acids in transgenics and controls, there was no difference whatever betwen 17 amino acids. Thus, transgenic fishes would have much more nutritious value than control fishes. It is reasonable that fishes with "fast growing and less eating" as well as "high protein content and low lipid content" traits will fulfil human increasing requirement on protein source from fishes.

Nevertheless, both the mouse metallothionein-1 (MT-1) gene promoter and the hGH structural gene are not suitable for the purpose of producing farming species of transgenic fish. It was urged to construct "all-fish" gene for transfer[42]. Researchers have cloned both common carp $\beta$-actin gene (CA)[49], and grass carp growth hormone gene (gcGH)[50], and subsenquetly made a new construct of pCAgcGH, an "all-fish" genomic construct with a powerful promoter of b-actin gene from common carp and the whole transcription unit of GH gene from grass carp. In the spring of 1997, this construct has been microinjected into the fertilized eggs of Yellow River Carp (Cyprinus Carpio L.), and a batch of CAgcGH-transgenic was produced. As these fishes grew up to 5 -month-old, body weight of the heaviest transgenic individual was $2.75 \mathrm{~kg}$, while that for the controls was $1.1 \mathrm{~kg}$. About $10 \%$ of the transgenics were over $2.0 \mathrm{~kg}$, while the controls were about $0.7 \mathrm{~kg}$ on average. It is more exciting that the heaviest body weight of 17-month-old transgenics, $7.65 \mathrm{~kg}$, was two fold and more than that of the control siblings [unpublished data]. Some experiments revealed further that the gene constructs with genetic elements derived from fish expressed more efficiently in fish cells than that from mammalian sp., e.g. the transcriptional activity of mouse MT promoter was only $1 / 2$ of that of carp MT promoter in CAT (chloramphenicol acetyl-transferase) genetransferred fish cells[51]. Till now, more than ten "all-fish" recombinant genes have been constructed all over the world[35]. The most dramatic growth acceleration came from Delvin et al., in which their pOnMTGH1-ransgenic salmon were more than 11-fold heavier than the controls on average[52].

It is very sensitive to talk about the biosafety of transgenic fish. There are food, genetic and ecological safeties, each of which should be concerned seriously. At present, the widely accepted principle on safety evaluation of foods produced by modern biotechnology was the "substantial equivalence principle" delivered by European OECD (Organization for Economic Cooperation and Development) in 1993[53]. According to this principle, “all-fish" transgenic carp is included in "level I", the safest level [54]. Studies from Cui's investigation revealed that the transgene could only flow among individuals within a species but not between species by natural reproduction[55]. Fish crossbreeding has been widely used in aquaculture, two sets of whole genome of different 
Embryonic and genetic manipulation in fish

species mixing with each other, i.e. $10^{5}$ genes of one species crossing with $10^{5}$ genes of another species. On the other hand, the "all-fish" gene transfer can also be regarded as a crossbreeding, but $10^{5}$ genes from one species cross with 1 gene of another species instead. It can be simply figured out that the hetrozygosity of genome in the CAgcGHtransgenic common carp is about 105 times less than that in the hybrids between common carp and grass carp. In other words, the risk of stocking "all-fish" gene transgenics is considerably on a lower level in comparison with stocking the hybrid fish. Nevertheless, people should take a cautious attitude towards the application of transgenics, since transgenic fish is still a "newborn" in comparison with naturally existing species that have undergone a long evolutionary and selective course. As polyploid-breeding in fish has been very popular during the past[56], this technique can also be employed in the breeding of transgenic fish. By crossing tetraploid individual with haploid transgenics, the infertile triploid strain of transgenic fish could be generated. It is reasonable to consider that stocking infertile strain of transgenic fish will lessen their impact on water ecosystem to the least degree.

\section{The prospect of transgenic fish}

Just as what has been discussed at the preceding part of this article, the transgenic fish generated at present is far from a genetic homogenous strain. Gene transfer in fish has not succeeded in the site-specific integration, controllable expression and stable transmission of the transgene. One of the most efficient ways to solve this problem is to use gene targeting technique in fish gene transfer. Gene targeting, homologous recombination between DNA sequence residing in the chromosome and newly introduced cloned DNA sequence, allows the transfer of any modified gene into the host genome of living cells. Since embryonic cell culture[4] and embryonic cell nuclear transplantation [2],[3] techniques have been developed in fishes, gene targeting is hopeful to be carried out to gain embryonic cell lines carrying artificially modified and site-specific integrated gene. By nuclear transplantation with gene-targeted embryonic cells, the genetic homogenous strain of transgenic fish can be generated. Additionally, to establish stem cell like lines in some model fish species, such as zebrafish and medakafish, were successfully reported[57-59]. If researchers can make great progress on the study of stem cell in farming fishes, it will be more convenient to generate homogenous strain of transgenic fish for aquaculture.

\section{REFERENCES}

[1] Nelson, JS. Fishes of the world. 2nd edition, A Wiley-interscience Pub: USA 1984.

[2] Tung TC, Wu SC, Tung YYF, Yan SY, Tu M, Lu TY.Nuclear transplantation in fish. Science bulletin, Academia Sinica (in Chinese) 1963; :60-1.

[3] Yan SY. Cloning in fish-Nuclear-cytoplasmic Hybrids. Educational and Cultural Press: Hong Kong 1998.

[4] Chen H, Yi Y, Chen M, Yang X. Studies on the developmental potentiality of cultured cell nuclei of fish. 


\section{Zhu ZY and YH Sun}

Acta Hydrobiol Sin (in Chinese) 1986; 10(1):1-7.

[5] Zhu Z, Li G, He L, Chen S. Novel gene transfer into the fertilized eggs of goldfish (Carassius auratus L. 1758). Z Angew Ichthyol 1985; 1:31-4.

[6] Spemann H. Embryonic development and induction. New Haven, CT: Yale University Press; 1938.

[7] Briggs R, King TJ. Transplantation of living nuclei from blastula cells into enucleated frog's eggs. Proc Natl Acad Sci USA 1952; 38:455-63.

[8] DiBerardino MA. Genomic potential of differentiated cells. New York: Columbia University Press; 1997.

[9] Gurdon JB. Adults frogs derived from the nuclei of single somatic cells. Dev Biol 1962; 4:256-73.

[10] Gurdon JB. The developmental capacity of nuclei taken from intestinal epithelium cells of feeding tadpoles. J Embryol exp Morph 1962; 10:622-40.

[11] Gurdon JB, Uehlinger V. "Fertile” intestine nuclei. Nature 1966; 210:1240-1.

[12] Gurdon JB, Laskey RA, Reeves OR. The development capacity of nuclei transplanted from keratinized skin cells of adults frogs. J Embryol exp Morph 1975; 34:93-112.

[13] Wabl MR, Brun RB, DuPasquier L. Lymphocytes of the toad Xenopus laevis have the gene set for promoting tadpole development. Science 1975; 190:1310-2.

[14] Di Berardino MA, Hoffner NJ. Gene reactivation in erythrocytes. Nuclear transplantation in oocytes and eggs of Rana. Science 1983; 219:862-4.

[15] Orr Hoffner N, Di Berardino MA, Mchinnell RG. The genome of frog erythrocytes displays centuplicate replications. Proc Natl Acad Sci USA 1986; 83:1369-73.

[16] Di Berardino MA, Orr Hoffner N, Mckinnell RG. Feeding tadpoles cloned from Rana erythrocyte nuclei. Proc Natl Acad Sci USA 1986; 83:8231-4.

[17] Di Berardino MA, Orr Hoffner N. Genomic potential of erythroid and leukocytic cells of Rana pipiens analyzed by nuclear transfer into diplotene and maturing oocytes. Differentiation 1992; 50:1-13.

[18] Illmensee K, Hoppe PC. Nuclear transplantation in Musmusculus: developmental potential of nuclei from preimplantation embryos. Cell 1981; 23:9-18.

[19] McGrath J, Solter D. Nuclear transplantation in the mouse embryo by microsurgery and cell fusion. Science 1983; 220:1300-2.

[20] Willadsen SM. Nuclear transplantation in sheep embryos. Nature 1986; 320:63-5.

[21] Prather RS, Barnes FL, Sims MM, et al. Nuclear transplantation in the bovine embryo: assessment of donor nuclei and recipient oocyte. Biol Reprod 1987; 37:859-66.

[22] Stice SL, Robl JM. Nuclear reprogramming in nuclear transplant rabbit embryos. Biol Reprod 1988; 39:657-64.

[23] Prather RS, Sims MM, First NL. Nuclear transplantation in early pig embryos. Biol Reprod 1989; 41: 123-32.

[24] Zhang Y, Wang JC Qian JF. Nuclear transplantation in goats. Theriogenology 1991; 35:289.

[25] Wilmut I, Schnieke AE, McWhir J, Kind AJ, Campbell KHS. Viable offspring derived from fetal and adult mammalian cells. Nature 1997; 385:810-3.

[26] Cibelli JB, Stice SL, Golueke PJ, et al. Cloned transgenic calves produced from nonquisent fetal fibroblast. Science 1998; 280:1256-8.

[27] Butler D French clone provides support for Dolly. Nature 1998; 392:113.

[28] Wakayama T, Perry AC, Zuccottti M, Johnson KR, Yanagimachi R. Full-term development of mice from enuleated oocytes injected with cumulus cell nuclei. Nature 1998; 394(6691):396-74.

[29] Kato Y, Tani T, Sotomaru Y, et al. Eight calves cloned from somatic cells of a single adult. Science 1998; 282:2095-8.

[30] Tung TC. Nuclear transplantation in teleosts. I. Hybrid fish from the nucleus of carp and the cytoplasm of crucian. Scientia Sinica (in Chinese)1980; 23(4):517-23.

[31] Yan SY, Lu DY, Zhu ZY, et al. Nuclear transplantation in teleosts. II. Hybrid fish from the nucleus of crucian and the cytoplasm of carp. Scientia Sinica (B) (in Chinese) 1984; 27(10):1029-34.

[32] Tung TC, Tung YFY, Lu TY, Tung SM, Tu M. Transplantation of nuclei between two subfamilies of 


\section{Embryonic and genetic manipulation in fish}

teleosts (Goldfish-domesticated Carassius auratus and Chinese bitterling, Rhodeus sinensis) Acta Zool Sin (in Chinese) 1973; 19(3):201-12.

[33] Yan SY, Lu DY, Du M, et al. Nuclear transplantation in teleosts. Nuclear transplantation between different subfamilies-hybrid fish from the nucleus of grass carp (Ctenopharyngoden idellus) and the cytoplasm of blunt-snout bream (Megalobrama amblycaephala). Chin Biotech (in Chinese) 1985; 1(4): 15-26.

[34] Palmiter RD, Brinster RL, Hammer RE, Trumbauer ME, Rosenfeld MG, Bimberg NC, Evans RM. Dramatic growth of mice that develop from eggs microinjected with metallothionein-growth hormone fusion gene. Nature 1982; 300:611-5.

[35] Cui Z, Zhu Z. Several interesting questions about breeding transgenic fish. J Biotech (in Chinese) 1998; (5):1-10.

[36] Houdebine LM, Chourrout D. Transgenesis in fish. Experentia 1991; 47(9):891-7.

[37] Xie Y, Liu D, Zou J, Li G, Zhu Z. Gene transfer via electroporation in fish. Aquaculture 1993; 111:20713.

[38] Khoo HW, Ang LH, Lim HB, et al. Sperm cells as vectors for introducing foreign DNA into zebrafish. Aquaculture, 1992; 107:1-19.

[39] Li G, Cui Z, Zhu Z, Huang S. Introduction of foreign gene carried by sperms. Acta Hydrobiol Sin (in Chinese) 1996; 20(3):242-7.

[40] Amsterdam A, Lin S, Hopkins N The Aequorea victoria green fluorescent protein can be used as a reporter in live zebrafish embryos. Dev Biol 1995; 171(1):123-9.

[41] Hew CL, Davies PL, Fletcher G. Antifreeze protein gene transfer in Atlantic salmon. Mol Mar Biol Biotechnol 1992; 1:309-17.

[42] Zhu Z, Xu K, Xie Y, Li G, He L. A model of transgenic fish. Scientia Sinica (B) (in Chinese) 1989; 2: 147-55.

[43] Hew CL. Transgenic fish: present status and future directions. Fish Physiology and Biochemistry 1989; 7:409-13

[44] Xu K, Wei Y, Guo L, Zhu Z. The effects of growth enhancement of human growth hormone gene transfer and human growth administration on crucian carp (Carassius auratus gibelio, Bloch). Acta Hydrobiol Sinica $1991 ; \mathbf{1 5 : 1 0 3 - 9 . ~}$

[45] Wei Y, Xie Y, Xu K, et al. Heredity of human growth hormone gene in transgenic carp (Cyprinus carpio L) Chinese J Biotech (in Chinese)1992; 8:140-4.

[46] Cui Z, Zhu Z, Cui Y, Li G, Xu K. Food consumption and energy budget in MThGH-transgenic F2 red carp ( Cyprinus carpio L. red var.). Chinese Science Bulletin (in English) 1996; 41:591-6.

[47] Fu C, Cui Y, Hung SSO, Zhu Z. Growth and feed utilization by F4 human growth hormone transgenic carp fed diets with different protein levels. J Fish Biol 1998; 53:115-29.

[48] Fu C. Growth and feed utilization by F4 human growth hormone transgenic red carp, Cyprinus Carpio L: effects of dietary protein level. Thesis for MSc (Supervised by Zuoyan Zhu) submitted to the Institute of Hydrobiology, Chinese Academy of Sciences 1998.

[49] Li Z, Zhu Z, Roberg K, et al. Isolation and characterization of b-actin gene of carp (Cyprinus carpio). DNA Sequence 1990; 1:125-36.

[50] Zhu Z, He L, Chen TT. Primary-structural and evolutionary analyses of growth-hormone gene from grass carp (Ctenopharyngodon idellus). Eur J Biochem 1992; 207:643-8.

[51] Li H, Liu DM, Ju DH, et al. Studies on the function of the promoter of carp (Cyprinus carpio) metallothionein gene. Acta Zool Sin (in Chinese) 1997; 43(2):197-202.

[52] Devlin RH, Yesakl TY, Blagl CA, Donaldson EM, Swanson P, Chan WK. Extraordinary salmon growth. Nature 1994; 371:209-10.

[53] OECD (Organization for Economic Cooperation and Development), Safety evaluation of foods produced by modern biotechnology: concepts and principles. OECD Paris 1993.

[54] Zhu Z, Zeng Z. Open a door for transgenic fish to market. J Biotech (in Chinese) (in press). 


\section{Zhu ZY and YH Sun}

[55] Cui Z. Biosafety assessment of GH- transgenic common carp (cyprinus carpio L.). Thesis for Ph. D. (Supervised by Zuoyan Zhu) submitted to the Institute of Hydrobiology, Chinese Academy of Sciences 1998.

[56] Zhang J, Sun X. The survey and prospect of fish genetics and breeding research. In: The Selected Paper of Breeding in Jian Carp (Cyprinus Carpio var. Jian) Written by Zhang J. Sun X. et al. Science Press Beijing 1994:pp1-10.

[57] Wakamatsu Y, Ozato K, Sasado T. Establishment of a pluripotent cell line derived from a medaka (Oryzias latipes) blastula embryo. Mol Mar Biol Biotechnol 1994; 3(4):185-91.

[58] Sun L, Bradford CS, Ghosh C, Cotllodi P, Barnes DW. ES-like cell cultures derived from early zebrafish embryos. Mol Mar Biol Dev 1995; 4:193-9.

[59] Hong Y, Schartl M. Establishment and growth responses of early medakafish (Oryzias latipes) embryonic cells in feeder layer-free cultures. Mol Mar Biol Biotechnol 1996; 5(2):93-104. 